\title{
AMERICAN VISCERAL LEISHMANIASIS: DISEASE CONTROL STRATEGIES IN DRACENA MICROREGION IN ALTA PAULISTA, SP, BRAZIL
}

\section{D'Andrea LAZ (1), Camargo-Neves VLF (2), Sampaio SMP (3), Kronka SN (4), Sartor IF $(4,5)$}

(1) Medical Biology Division, Adolfo Lutz Institute, Regional Laboratory of Presidente Prudente, Presidente Prudente, São Paulo State, Brazil; (2) Group for Studies on Leishmaniasis, Superintendence for Endemic Disease Control, SUCEN, Disease Control Coordinator, São Paulo, São Paulo State, Brazil; (3) Superintendence for Endemic Disease Control, SUCEN, Presidente Prudente, São Paulo State, Brazil; (4) University of Western São Paulo, UNOESTE, Presidente Prudente, São Paulo State, Brazil; (5) São Paulo State University, UNESP, Botucatu, São Paulo State, Brazil.

\begin{abstract}
Despite measures adopted to control American visceral leishmaniasis $(A V L)$, the disease is spreading in a fast and worrying way throughout western São Paulo state. The aim of this work was to study the variables involved in the disease cycle as well as the effectiveness of controlling measures. The study was carried out in the microregion of Dracena, which is composed of twelve cities and belongs to Alta Paulista, a region of western São Paulo. The necessary data were provided by the Superintendence for Endemic Disease Control and Adolfo Lutz Institute, Regional Laboratory of Presidente Prudente. From August 2005 to January 2008, the following factors were observed: detection of phlebotomine sandflies in the cities and periods in which dogs or humans were diagnosed; number of human deaths; prevalence of suspected dogs tested by serology; percentage of euthanasia in suspected dogs; a possible correlation between positive dogs and cases of the disease in humans; and the disease prevalence among municipalities from the studied region. It was verified that, despite the strategies adopted in Dracena microregion to control AVL, the disease continues to rise. Thus, some procedures of the AVL Monitoring and Control Program should be reviewed, to grant the initiative more credibility and effectiveness.
\end{abstract}

CONFLICTS OF INTEREST: There is no conflict.

KEY WORDS: visceral leishmaniasis, seroprevalence, control strategies, São Paulo, Brazil.

\section{CORRESPONDENCE TO:}

LOURDES APARECIDA ZAMPIERI D'ANDREA, Seção de Biologia Médica, Laboratório Regional de Presidente Prudente, Instituto Adolfo Lutz, IAL, Av. Cel. José Soares Marcondes, 2357, Presidente Prudente, SP, 19.013-050, Brasil. Phone: +55 182221 1888. Fax: +55 182221 5814. Email: zampieri@ial.sp.gov.br. 


\section{INTRODUCTION}

Leishmaniasis is considered a serious zoonosis, provoked by a protozoan of the genus Leishmania, that may affect humans who get into contact with the parasite transmission cycle, thus becoming an antropozoonosis (1). The American visceral leishmaniasis (AVL) is caused by a species of the subgenus Leishmania, Leishmania chagasi (2). Clinical manifestations of the disease and its severity are associated with malnutrition and to host immune response $(3,4)$. There is a connection between AVL and immunosuppression caused by acquired immunodeficiency syndrome (AIDS) and other diseases including microbacteriosis, cytomegalovirus infection and Kaposi's sarcoma; hence, it constitutes an opportunistic pathology among immunosuppressed patients who lives in endemic areas (5-7).

Different types of phlebotomine sandflies can transmit AVL. In the Americas, Lutzomyia (Lutzomyia) longipalpis is the main species, present in virtually all areas of occurrence of leishmaniasis (8). However, there are reports of transmission by $L$. cruzi in cities like Corumbá and Ladário (Mato Grosso do Sul state, Brazil) $(9,10)$. Additionally, Marzochi and Marzochi (2) suggested an association between the disease and L. intermedia in coastal areas of Rio de Janeiro city. L. longipalpis life cycle takes place in soil, in wet and shaded places that are also rich in organic matter. Only females are bloodsuckers, feeding on numerous warm-blooded vertebrates (11). According to a recent study carried out in São Paulo state, it appears that $L$. longipalpis prefer to feed on dogs (12). Although this species can be found throughout the year, there are seasonal variations of population density, depending on geographic region and some factors like temperature, humidity and wind speed (13).

Despite its wide worldwide distribution, ALV is predominant in tropical and subtropical regions, occurring in Asia, Europe, Middle East, Africa and the Americas. In Latin America, the disease has already been described in at least 12 countries, with $90 \%$ of cases in Brazil. Nowadays, leishmaniasis is present in four out of five Brazilian geographic regions, mainly in the Northeast. However, over the years, it has spread to the north, southeast and central west, with different geographical, climatic and social aspects, due to its wide distribution (14).

The first record of L. longipalpis in the State of São Paulo (SSP) occurred in the 1970s, in a specific area on the Mantiqueira mountain range, in the east of the state (15). In 1997, this vector was identified in western SSP, in Araçatuba city, followed by 
the discovery of $L$. chagasi infection in dogs, in 1998, and in humans, in 1999. Since then, the disease has been reported in several regions, with exclusively urban transmission (16-18). In eastern SSP, the spreading occurred from west to east and, more recently, from north to south of Minas Gerais state (12). Therefore, control measures are being implemented in order to reduce human morbidity and mortality by AVL in SSP $(14,19)$.

There have been important changes in the disease transmission pattern. Initially, it was predominant in rural and periurban areas and, later, in urban centers including the cities of Rio de Janeiro (RJ), Corumbá (MS), Belo Horizonte (MG), Araçatuba (SP), Palmas (TO), Três Lagoas (MS) and Campo Grande (MS).

The adaptation of the vector to urban environment happened slowly. It was first recorded in municipalities neighboring Araçatuba and subsequently in cities that had migratory flow of both population and goods. Then, it was detected in other administrative regions - such as Bauru (SP), Marília (SP) and Presidente Prudente (SP) - crossed by major roads and railways axes. Recently, it was found in the region of São João da Boa Vista (SP), which presents different climatic and topographic characteristics from those observed in western Planalto Paulista; thus, proving $L$. longipalpis ability to adapt to anthropic environments (12).

The São Paulo State Secretary of Health created the AVL Monitoring and Control Program (AVLMCP) in order to reduce both the mortality and lethality of the disease. The program actions are based on three strategic pillars, similar to the Ministry of Health Program: early diagnosis and treatment of human cases, monitoring and reduction of sandfly population density, and control of $L$. (L.) chagasi domestic reservoirs represented by seropositive dogs. The antivectorial activities include epidemiological surveillance plans such as: entomological survey; entomological research of infestation focus and fixed units; notification of insects by population; prevention and control initiatives that include environmental management, chemical control and educational projects. Another key point of AVLMCP is the control of canine reservoirs through serological surveys and sample census in affected cities (14).

Canine infection has usually preceded the occurrence of human cases and has been more prevalent than the human disease (20). Therefore, it is very important to know the prevalence of infected dogs in a given region. 
This study aimed carry out a time-space analysis of the prevalence of circulating antibodies against Leishmania sp. in blood samples of dogs and its correlation with the incidence of human cases. Additionally, we assessed the effectiveness of removing canine reservoirs as a controll strategy in cities from the microregion of Dracena, Alta Paulista (SP), from August 2005 to January 2008.

\section{MATERIAL AND METHODS}

\section{Description of the Studied Area}

The study was conducted in Alta Paulista, a region that comprises the Dracena microregion, between the rivers Feio (or Aguapeí) and Peixe, which is composed by twelve cities: Dracena, Junqueirópolis, Monte Castelo, Nova Guataporanga, Ouro Verde, Panorama, Paulicéia, Santa Mercedes, São João do Pau d'Alho, Tupi Paulista, Flora Rica and Irapuru. The total human population estimated in this region is 121,976 inhabitants while dogs are 30,022 (Table 1) $(21,22$ ). Alta Paulista is located at $21^{\circ} 28^{\prime} 57 \mathrm{~S}$ latitude and $51^{\circ} 31^{\prime} 58^{\prime \prime} \mathrm{W}$ longitude, being a hot and humid tropical region, with one or two months of drought, whose average temperature is above $18^{\circ} \mathrm{C}$ throughout the year (23). It is part of the $10^{\text {th }}$ administrative region of São Paulo state, $55 \mathrm{~km}$ away from Adamantina, $110 \mathrm{~km}$ from Presidente Prudente, 200 $\mathrm{km}$ from Marília, $647 \mathrm{~km}$ from São Paulo city and $40 \mathrm{~km}$ from the state border with Mato Grosso do Sul, near Paraná River's new lake that turned the region into a tourist attraction of the state. It is one of the poorest regions in São Paulo state, along with the Vale do Rio Ribeira de Iguape, with a literacy rate of 83.93\% (24). 
Table 1. Estimated distribution of human and canine population in Dracena microregion, Alta Paulista (SP), 2007

\begin{tabular}{c|c|c}
\hline Cities & Human population* & Canine population** $^{*}$ \\
\hline Dracena & 42,107 & 10,052 \\
\hline Flora Rica & 2,019 & 505 \\
\hline Irapuru & 7,556 & 1,890 \\
\hline Junqueirópolis & 18,628 & 4,660 \\
\hline Monte Castelo & 4,014 & 1,003 \\
\hline Nova Guataporanga & 2,101 & 525 \\
\hline Ouro Verde & 7,668 & 1,917 \\
\hline Panorama & 13,944 & 3,486 \\
\hline Paulicéia & 5,506 & 1,376 \\
\hline Santa Mercedes & 2,589 & 647 \\
\hline São João do Pau d'Alho & 2,132 & 533 \\
\hline Tupi Paulista & 13712 & 3,428 \\
\hline Total & 121,976 & $\mathbf{3 0 , 0 2 2}$ \\
\hline
\end{tabular}

*IBGE (21); **Alves et al. (22).

\section{Sampling}

Data herein presented are from serological surveys officially accomplished by SUCEN in accordance with AVLMCP. The tests were performed in all cities belonging to Dracena microregion, from August 2005 to January 2008.

\section{AVL Diagnosis}

Human and canine AVL diagnoses were carried out by the Adolfo Lutz Institute, Regional Laboratory of Presidente Prudente (SP), which is the regional reference for this disorder. Samples were processed in the Medical Biology section, Serology and Parasitology sector, after being sent by Superintendence for Endemic Disease Control, SUCEN, of Presidente Prudente, Brazil. 


\section{Direct Parasitological Diagnosis}

The direct technique for leishmaniasis diagnosis was utilized to detect the amastigote form of the parasite, both in human and animal hosts. Several procedures were employed, including bone marrow puncture, leucocitary cream, aspiration of wounds and lymph nodes, biopsy of injuries and guts. The samples were prepared on stained laminas with Giemsa or Leishman and examined on an optical microscope (100x).

\section{Serological Diagnosis}

Samples of whole blood tested for dog AVL were obtained by lancet puncture of the marginal ear vein and immediately transferred to a standardized filter paper, such as Watmann number 1 or Klabin (Klabin Co., Brazil), as recommended by the Manual of Surveillance and Control of American Visceral Leishmaniasis of São Paulo state. The blood drenched area covered a diameter of $3 \mathrm{~cm}$ (14). This material was subsequently fixed in phosphate buffered saline solution (PBS), $\mathrm{pH} 7.2$, originating the eluate. All samples were labeled with the animal name, registration number, date, city, sector and the collection responsible. The samples were kept at room temperature (RT) or at $4^{\circ} \mathrm{C}$ for a period of 30 days after collection or up to 60 days at $-20^{\circ} \mathrm{C}$, protected in moisture-free plastic bags.

The EIE Bio-Manguinhos/Fundação Oswaldo Cruz kit was employed for the canine leishmaniasis diagnosis, according to their recommendations. Filter paper was used in this immunoenzymatic assay, as described by Evans et al. (25), with $79.45 \%$ sensitivity and 90.24\% specificity. The indirect immunofluorescence BioManguinhos/Fundação Oswaldo Cruz kit for canine leishmaniasis diagnosis was also used, according to the manufacturer recommendations. The reaction of indirect fluorescent antibody test (IFAT) was carried out on samples collected on filter paper, to detect class IgG antibodies, according to the methodology described by Camargo and Rebonato (26) and Costa et al. (27) with 90\% sensitivity and 80\% specificity. Slides were prepared with a $10-\mu \mathrm{L}$ suspension of $L$. like major promastigotes, fixed in air for 12 hours or for two hours at $37^{\circ} \mathrm{C}$ and incubated with 1:40 diluted eluate. Connected antibodies were detected with the total conjugated anti-immunoglobulin of dog stained with fluorescein, diluted in PBS with Evans Blue at 0.004\%. 


\section{Statistical Analysis}

The average prevalence of Leishmania sp. antibodies was calculated taking into account the total number of animals tested and seroreactives. The chi-square $\left(\chi^{2}\right)$ test was employed to compare the prevalence among the cities. The simple linear coefficient was used to verify a possible association between positive dogs and AVL human cases (28).

\section{RESULTS AND DISCUSSION}

The cities of Dracena and Nova Guataporanga were the first where the presence of L. longipalpis was detected, in 2003. Subsequently, in 2004, the sandfly was also observed in Tupi Paulista, Junqueirópolis, Monte Castelo, Flora Rica, Santa Mercedes and São João do Pau D'Alho. In 2005, all the cities comprising Dracena microregion had already registered the presence of this vector. Both canine and human infections were identified from one to three years after $L$. longipalpis detection. Its spread reached even adjacent cities, such as President Venceslau, where the vector was found in January 2008 (Table 2). 
Table 2. Years of detection of $L$. longipalpis and canine and human AVL transmission in 12 cities belonging to Dracena microregion, Alta Paulista (SP), as well as neighboring cities

\begin{tabular}{|c|c|c|c|}
\hline \multirow[b]{2}{*}{ Cities } & \multicolumn{3}{|c|}{ Year of detection } \\
\hline & L. longipalpis & $\begin{array}{c}\text { Canine } \\
\text { transmission }\end{array}$ & $\begin{array}{c}\text { Human } \\
\text { transmission }\end{array}$ \\
\hline Dracena & Mar. 2003 & 2005 & 2005 \\
\hline Ouro Verde & Feb. 2004 & 2006 & 2006 \\
\hline Tupi Paulista & Apr. 2004 & 2006 & 2006 \\
\hline Nova Guataporanga & Apr. 2003 & 2007 & 2007 \\
\hline Junqueirópolis & Apr. 2004 & 2006 & 2006 \\
\hline Monte Castelo & Feb. 2004 & 2008 & - \\
\hline Flora Rica & Dec. 2004 & - & - \\
\hline Santa Mercedes & Dec. 2004 & 2007 & 2007 \\
\hline S. J. P. Alho & Dec. 2004 & - & - \\
\hline Paulicéia & Feb. 2005 & 2007 & 2007 \\
\hline Panorama & Feb. 2005 & 2007 & 2007 \\
\hline Irapuru & Oct. 2005 & 2007 & 2007 \\
\hline Presidente Venceslau & Feb. 2008 & - & - \\
\hline
\end{tabular}

Source: SUCEN/IAL - Presidente Prudente.

The parasite detection and both clinical and epidemiological criteria were employed to confirm human AVL. A total of 155 AVL human cases were recorded in the microregion of Dracena, Alta Paulista (SP), from August 2005 to January 2008, with seven deaths (Table 3). 
D'Andrea LAZ et al. American visceral leishmaniasis: disease control strategies in Dracena microregion in Alta Paulista, SP, Brazil. J Venom Anim Toxins incl Trop Dis. 2009;15(2):313

Table 3. AVL cases and human deaths in Dracena microregion, Alta Paulista (SP), from August 2005 to January 2008

\begin{tabular}{|c|c|c|c|c|c|c|c|c|}
\hline \multirow{2}{*}{ Cities } & \multicolumn{2}{|c|}{2005} & \multicolumn{2}{|c|}{2006} & \multicolumn{2}{|c|}{2007} & \multicolumn{2}{|c|}{2008} \\
\hline & Cases & Deaths & Cases & Deaths & Cases & Deaths & Cases & Deaths \\
\hline Dracena & 8 & - & 41 & 1 & 38 & - & 2 & \\
\hline Junqueirópolis & - & - & 3 & - & 10 & 1 & 2 & \\
\hline Nova Guataporanga & - & - & - & - & 2 & 2 & - & \\
\hline Ouro Verde & 1 & - & 4 & 1 & 5 & - & 1 & \\
\hline Panorama & - & - & - & - & 10 & 1 & 2 & \\
\hline Paulicéia & - & - & - & - & 2 & - & 2 & \\
\hline Tupi Paulista & - & - & 2 & - & 7 & 1 & 1 & \\
\hline Irapuru & - & - & - & - & 1 & - & - & \\
\hline Santa Mercedes & - & - & - & - & 3 & - & 1 & \\
\hline Total & 9 & 0 & 50 & 2 & 78 & 5 & 11 & \\
\hline
\end{tabular}

Source: www.cve.saude.sp.gov.br

In this microregion, canine exams were carried out as recommended by AVLMCP (14), with an overall average prevalence of Leishmania sp. antibodies of $23.78 \%$, ranging between 0 and $30.03 \%$ (Table 4). Of 29,995 tested dogs, 7,133 were seroreactive to Leishmania sp., among which only $62.44 \%(4,454)$ were killed in the studied region (Table 5). 
D'Andrea LAZ et al. American visceral leishmaniasis: disease control strategies in Dracena microregion in Alta Paulista, SP, Brazil. J Venom Anim Toxins incl Trop Dis. 2009;15(2):314

Table 4. Mean antibody prevalence of Leishmania sp. among dogs from Dracena microregion, Alta Paulista (SP), from August 2005 to January 2008

\begin{tabular}{|c|c|c|c|c|c|}
\hline Cities & Inquiries (n) & Total analyzed & Positive results (n) & $\begin{array}{c}\text { Inconclusive } \\
\text { results }\end{array}$ & Mean prevalence (\%) \\
\hline Dracena & 3 & 11,675 & 3,415 & 2,263 & $29.25 \%$ \\
\hline Junqueirópolis & 3 & 5,268 & 705 & 1,172 & $13.38 \%$ \\
\hline Tupi Paulista & 2 & 4,200 & 761 & 1,257 & $18.12 \%$ \\
\hline Ouro Verde & 3 & 2,693 & 746 & 776 & $27.70 \%$ \\
\hline Paulicéia & 2 & 1,150 & 343 & 217 & $29.81 \%$ \\
\hline Santa Mercedes & 2 & 726 & 218 & 111 & $30.03 \%$ \\
\hline Panorama & 2 & 3,190 & 889 & 18 & $27.87 \%$ \\
\hline Flora Rica & 1 & 195 & 5 & 0 & $2.50 \%$ \\
\hline Irapuru & 1 & 348 & 40 & 192 & $11.49 \%$ \\
\hline Monte Castelo & 1 & 224 & 11 & 0 & $4.91 \%$ \\
\hline Nova Guataporanga & 1 & 162 & 0 & 0 & $0.00 \%$ \\
\hline S. J. P. Alho & 1 & 164 & 0 & 0 & $0.00 \%$ \\
\hline Total & 22 & 29,995 & 7,133 & 6,006 & $23.78 \%$ \\
\hline
\end{tabular}

Source: SUCEN/IAL - Presidente Prudente. 
D'Andrea LAZ et al. American visceral leishmaniasis: disease control strategies in Dracena microregion in Alta Paulista, SP, Brazil. J Venom Anim Toxins incl Trop Dis. 2009;15(2):315

Table 5. Porcentage of euthanasia in AVL seroreactive dogs in the cities of Dracena microregion, Alta Paulista (SP), from August 2005 to January 2008

\begin{tabular}{c|c|c|c}
\hline \multirow{2}{*}{ Cities } & \multirow{2}{*}{ Positives } & \multicolumn{2}{|c}{ Euthanasia } \\
\cline { 3 - 4 } & & Number & (\%) \\
\hline Dracena & 3,415 & 2,299 & 67.32 \\
\hline Junqueirópolis & 705 & 644 & 91.34 \\
\hline Tupi Paulista & 761 & 628 & 82.52 \\
\hline Ouro Verde & 746 & 379 & 50.80 \\
\hline Paulicéia & 343 & 169 & 49.27 \\
\hline Santa Mercedes & 218 & 186 & 85.32 \\
\hline Panorama & 889 & 528 & 59.39 \\
\hline Flora Rica & 5 & - & - \\
\hline Irapuru & 40 & - & - \\
\hline Monte Castelo & 11 & - & $\mathbf{6 2 . 4 4}$ \\
\hline Nova Guataporanga & 0 & - & - \\
\hline S. J. P. Alho & 0 & $\mathbf{4 , 4 5 4}$ & - \\
\hline Total & 733 & & - \\
\hline
\end{tabular}

Source: SUCEN/IAL - Presidente Prudente.

The correlation coefficient was 0.98 (significant level of 1\%), revealing an association between the total number of human cases of leishmaniasis and the number of dogs that reacted to Leishmania sp. (Table 6). 
Table 6. Total number of human leishmaniasis cases $(\mathrm{Y})$ and positive results among dogs $(X)$ in Dracena microregion, Alta Paulista (SP), from August 2005 to January 2008

\begin{tabular}{c|c|c}
\hline Cities & Positive dogs (X) & Human leishmaniasis cases (Y) \\
\hline Dracena & 3,415 & 90 \\
\hline Junqueirópolis & 705 & 16 \\
\hline Tupi Paulista & 761 & 11 \\
\hline Ouro Verde & 746 & 12 \\
\hline Paulicéia & 343 & 4 \\
\hline Santa Mercedes & 218 & 4 \\
\hline Panorama & 889 & 13 \\
\hline Flora Rica & 5 & 0 \\
\hline Irapuru & 40 & 1 \\
\hline Monte Castelo & 11 & 0 \\
\hline Nova & 0 & 4 \\
\hline Guataporanga & 0 & 155 \\
\hline S. J. P. Alho & $\mathbf{7 , 1 3 3}$ & 0 \\
\hline Total & & 13 \\
\hline
\end{tabular}

Correlation coefficient $(r=0.98)$ significant in the level of $1 \%$, where $\hat{\mathbf{Y}}=-\mathbf{3 , 4 2 2 4}+\mathbf{0 , 0 2 3 4 X}$ It shows the existence of an association between the number of human leishamaniasis cases $(Y)$ and the number of positive dogs $(X)$.

According Table 7, chi-square test $\left(\chi^{2}\right)$, utilized to compare the prevalence among cities of Dracena microregion, revealed that $a>b>c>d>e$, where different letters indicate significant differences among cities. Cities where Leishmania sp. antibodies were more prevalent, like Santa Mercedes (a: 30.03\%), Paulicéia (a: 29.83\%), Dracena (a: 29.25\%), Panorama (a: 27.87\%) and Ouro Verde (a: $27.70 \%$ ), presented no significant difference among them ( $p>0.05$ ). On the other hand, Tupi Paulista ( $b$ : 18.12\%) showed a significant statistical difference when compared to other cities ( $\mathrm{p}<$ 0.05). There was no difference between Junqueirópolis (c: $13.38 \%$ ) and Irapuru (c: $11.49 \%$ ); however, comparison between Monte Castelo (d: 4.91\%) and Flora Rica (d: $2.56 \%)$ revealed significant difference. No circulating Leishmania sp. antibodies 
were found in the cities of Nova Guataporanga (e: 0\%) and São João do Pau D'Alho (e: 0\%) until January 2008.

Table 7. Comparison of the disease prevalence by chi-squared test of cities from Dracena microregion, Alta Paulista (SP), from August 2005 to January 2008

\begin{tabular}{|c|c|c|c|c|c|c|c|c|c|c|c|c|c|c|}
\hline 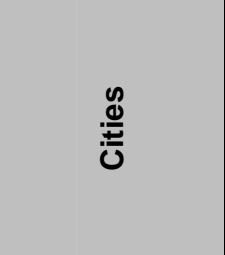 & $\begin{array}{l}\text { ఏ } \\
\frac{0}{0} \\
\frac{0}{0} \\
\frac{0}{0} \\
\frac{0}{0}\end{array}$ & & 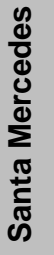 & 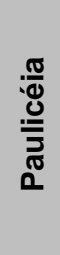 & 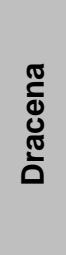 & 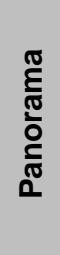 & $\begin{array}{l}\frac{0}{0} \\
\frac{0}{0} \\
\frac{0}{3} \\
0\end{array}$ & $\begin{array}{l}\frac{\pi}{0} \\
\frac{0}{5} \\
\frac{0}{\pi} \\
\frac{0}{2} \\
\frac{0}{2}\end{array}$ & $\begin{array}{l}\frac{n}{0} \\
\frac{0}{0} \\
\frac{0}{0} \\
\frac{0}{2} \\
\frac{0}{2} \\
\frac{5}{n}\end{array}$ & 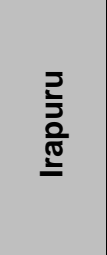 & 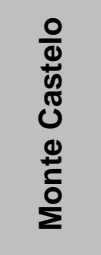 & $\begin{array}{l}\frac{\pi}{0} \\
\frac{\pi}{\alpha \pi} \\
\frac{0}{4}\end{array}$ & ๘ & 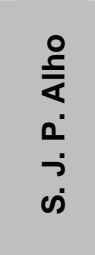 \\
\hline $\begin{array}{c}\text { Santa } \\
\text { Mercedes }\end{array}$ & 30.03 & a & - & NS & NS & NS & NS & Signif. & Signif. & Signif. & Signif. & Signif. & Signif. & Signif. \\
\hline Paulicéia & 29.83 & a & - & - & NS & NS & NS & Signif. & Signif. & Signif. & Signif. & Signif. & Signif. & Signif. \\
\hline Dracena & 29.25 & a & - & - & - & NS & NS & Signif. & Signif. & Signif. & Signif. & Signif. & Signif. & Signif. \\
\hline Panorama & 27.87 & a & - & - & - & - & NS & Signif. & Signif. & Signif. & Signif. & Signif. & Signif. & Signif. \\
\hline Ouro Verde & 27.70 & a & - & - & - & - & - & Signif. & Signif. & Signif. & Signif. & Signif. & Signif. & Signif. \\
\hline Tupi Paulista & 18.12 & b & - & - & - & - & - & - & Signif. & Signif. & Signif. & Signif. & Signif. & Signif. \\
\hline Junqueirópolis & 13.38 & c & - & - & - & - & - & - & - & NS & Signif. & Signif. & Signif. & Signif. \\
\hline Irapuru & 11.49 & c & - & - & - & - & - & - & - & - & Signif. & Signif. & Signif. & Signif. \\
\hline Monte Castelo & 4.91 & d & - & - & - & - & - & - & - & - & - & NS & Signif. & Signif. \\
\hline Flora Rica & 2.56 & $d$ & - & - & - & - & - & - & - & - & - & - & Signif. & Signif. \\
\hline $\begin{array}{c}\text { Nova } \\
\text { Guataporanga }\end{array}$ & 0.00 & e & - & - & - & - & - & - & - & - & - & - & - & NS \\
\hline S. J. P. Alho & 0.00 & e & - & - & - & - & - & - & - & - & - & - & - & - \\
\hline
\end{tabular}

NS: results were not significant $(p>0.05)$; Signif.: results were significant $(p<0.05)$; $a$, b, etc.: prevalence followed by the same letter does not differ.

L. longipalpis was first detected in the urban area of Dracena, in March 2003, and the first cases of canine and human AVL were reported in 2005. Since then, the vector has adapted very well in the region, being detected in 12 cities since October 2005, when canine and human AVL cases spread. Initially, up to 2007, L. Iongipalpis was restricted only to municipalities from Dracena microregion. In February 2008, the phlebotomine sandfly was found in President Venceslau, a city contiguous to the affected region. This was an evidence of the great adaptability of $L$. longipalpis in neighboring areas, thus, confirming the spread of the disease. The dissemination of 
the disease, in both dogs and humans, may be very rapid once its transmitter is detected, as shown in Table 2. As a result, the monitoring of cities must be on full alert to prevent a possible epidemic (Figure 1).

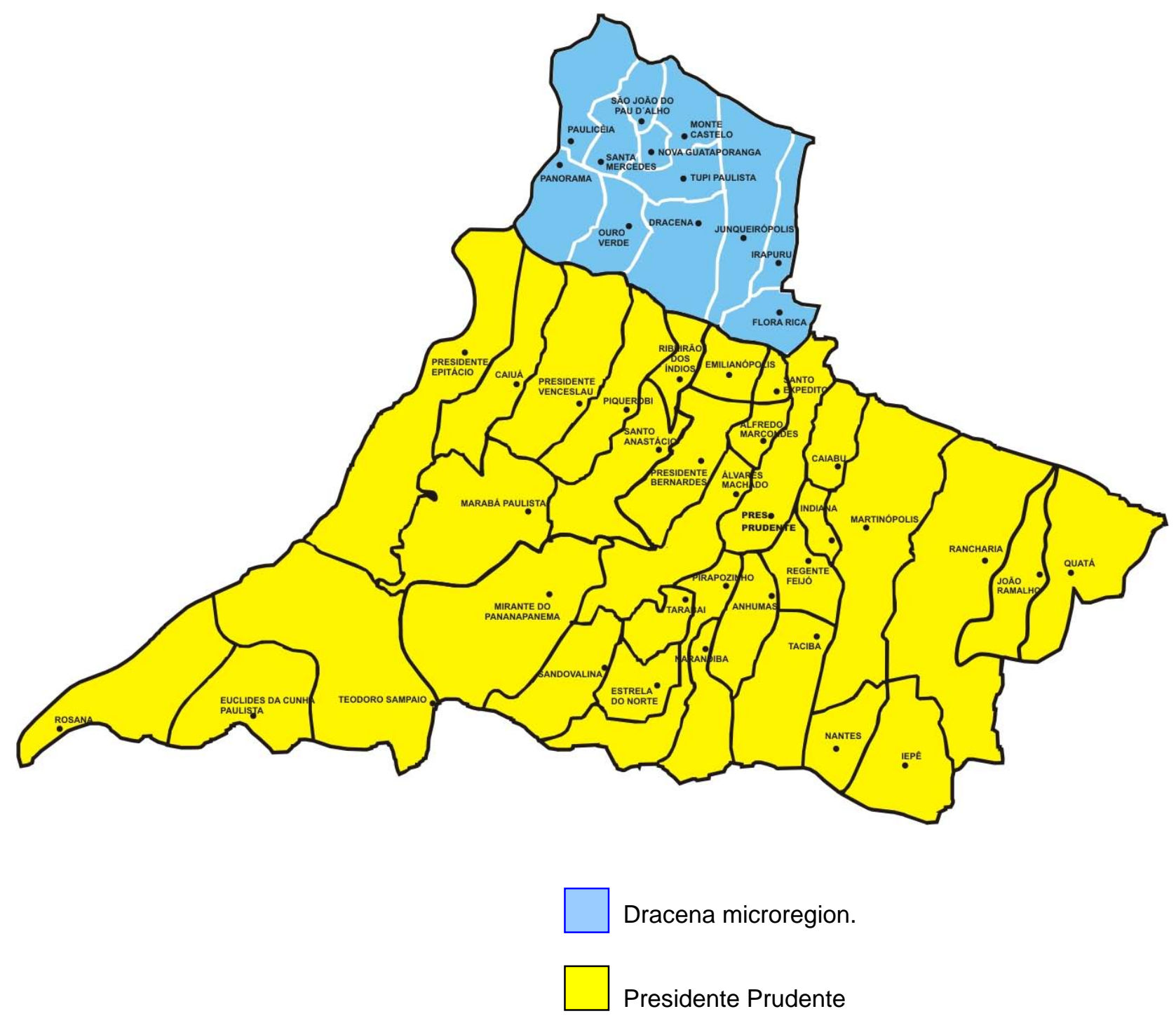

Figure 1. Cities of the $11^{\text {th }}$ Regional Division of Health - Presidente Prudente.

Inadequate environmental supervision and poor socioeconomic conditions constitute a weak point of difficult solution for the program. Regarding environmental management, it is necessary to implement an awareness campaign, both in cities where the disease was not observed and in those where the problem is already 
present. The campaign would involve modifications in procedures long employed by the population, such as the use of organic matter as a natural fertilizer, which is the substrate for the vector biological cycle. The expected changes in cultural behavior pattern concerning leishmaniasis will only be achieved over the time through educational campaigns, whose goals are to form eco-literate individuals in all segments of the society, involving children and engaged professionals.

The importance of proper soil management to control the AVL vector and, thus, control the disease, was also described by Lindoso et al (23). Barão et al. (29), in a study on the prevalence of AVL in Araçatuba (SP), affirmed that poor socioeconomic and environmental conditions intensify the incidence of the disease. Additionally, Carvalho (30) reported similar conditions that facilitate the proliferation of sandflies, enabling the AVL transmission.

In the cities where AVL has not yet been confirmed, the direct research method should be employed in suspected dogs. Furthermore, it is necessary to identify the species of Leishmania sp. in these places, since from this assumption serological surveys are carried out. Two criteria were used for notifying AVL human cases from 2005 to 2008 in the region (Table 3): the laboratorial criterion, based on positivity of direct parasitology, and the clinical/epidemiological one, in those cities where canine and human transmission were confirmed. The clinical/epidemiological criterion has been used due to the shortage of trained and skilled professionals to collect bone marrow puncture. The presumptive diagnosis, as well as the therapeutic one, has helped the program by reducing the number of deaths in suspected patients.

The serological survey census was carried out in all dogs from the area delimited by municipalities with confirmed AVL transmission, vulnerable receptive places and those under investigation (Table 4). The average prevalence of Leishmania sp. antibodies was $23.78 \%$, revealing that the disease is installed and spreading through the region. IFAT was employed in investigations of outbreaks and to confirm reagent presence among samples (Table 4).

Despite of this, in cities where the canine AVL had already been confirmed, the São Paulo State Secretary of Health and the Brazilian Ministry of Health required two serological analyses for dogs - anti-Leishmania IgG antibody tests - to consider them positive for the disease, ELISA for "sorting" and IFAT to confirm the results. The latter technique is considered the "gold standard" for confirmation of infected animals (31). Following studies could explain which one is the best "gold standard". However, 
in the absence of ELISA, IFAT is the technique of choice to define the diagnosis of animals that tested positive for the disease (14). If there is no confirmation of IFAT reactivity, the sample is considered inconclusive; then, the test should be repeated with new sampling, within a minimum period of 15 days and a maximum of 30 days after the first collection. Afterwards, the sample will be subject only to IFAT method (14). According to the suppliers of anti-Leishmania antibody tests, there is an inconsistency in use procedures to obtain a final result, regarding sensitivity and specificity, which determines whether or not the dog will be killed, a problem also reported by Braga et al. (32). Since IFAT presents greater sensitivity, it would be more useful in the "sorting", while ELISA -with greater specificity - would guarantee the accuracy of the infection suspicion.

During the studied period in Alta Paulista, a total of 6,006 (20.02\%) samples presented inconclusive results and were retested in order to verify seroconversion. This fact jeopardizes AVLMCP and contributes to the disease spread, since it overloads the reference laboratory - that has a capacity of 2,000 tests per month and the cities that are forced to carry out new collections, consequently delaying the program progress and the reservoir elimination. Another problem in serological tests is occurrence of false positive results provoked by $L$. (L.) chagasi infection in cases of ehrlichiosis, babesiosis, cutaneous leishmaniasis, Chagas' disease, among others. Araújo (33) presented an alternative with the rK39 immunochromatographic method (rK39 test), an analysis carried out on immunocromatography paper covered with the recombinant antigen K39. This test is considered rapid, sensitive and specific for confirmation of canine visceral leishmaniasis infections in routine diagnostic and epidemiological studies (33).

The use of such procedures casts doubt on result reliability, because seropositivity alone does not mean that the animal has a latent infection. Therefore, methods such as PCR should be used as "gold standard" to detect causative agents and antibody detection methods used only as tracers.

Taking into account the increased number of AVL human cases and deaths due to the disease in the region (Table 3), as well as the significant correlation between the increase in the canine prevalence and in human cases (Table 6), it is essential to implement more effective measures to control $A V L$, in order to reduce the infection among animals. Since treatment is not recommended, because treated dogs become inapparent reservoirs, the only option left would be kill of seroreactive dogs. This 
initiative, however, is not being carried out in its fullness, since only $62.44 \%$ of seroreactive animals were killed (Table 5). This finding corroborates Braga et al. (32), who suggest a reduction of the period that an infected animal remains in a community and detection through a more sensitive technique of AVL antibodies.

This study noticed a high presence of antibodies against canine AVL in Dracena microregion. Among the studied cities, Dracena was the first to detect both canine and human transmission and it is among the five places with the higher prevalence, demonstrating the low effectiveness of disease control strategies in the region. It is important to point out that the results shown here date back to January 2008 and that nowadays the transmission of canine AVL can be found in all cities of the region.

\section{CONCLUSIONS}

Despite the adopted strategies to control AVL in Dracena microregion, Alta Paulista (SP), the disease continues its spread. Some procedures of the AVL monitoring and control program should be revised, aiming at improving its reliability and effectiveness.

\section{REFERENCES}

1. World Health Organization. Division of control of tropical disease. Leishmaniasis control. Geographical distribution. WHO/CTA [Internet]. 2005. Available from: http://www.who.int/ctd/html/leisgeo.html.

2. Marzochi MCA, Marzochi KBF. Tegumentary and visceral leishmaniasis in Brazil. Emerging anthroponosis and possibilities for their control. Cad Saúde Pública. 1994;10(Suppl 2):359-78.

3. Harisson LH, Naidu TG, Drew JS, de Alencar JE, Pearson RD. Reciprocal relationships between undernutrition and parasitic disease visceral leishmaniasis. Rev Infec Dis. 1986;8(3):447-53.

4. Pearson RD, Cox G, Jeronimo SM, Castracane J, Drew JS, Evans T, de Alencar JE. Visceral leishmaniasis: a model for infection-induced cachexia. Am J Trop Med Hyg. 1992;47(1 pt 2):8-15.

5. Lindoso JAL, Goto H. Leishmaniose visceral: situação atual e perspectivas futuras. BEPA Bol Epidem Paul. 2006;3(26):7-11. 
6. Badaró R, Rocha H, Carvalho EM, Queiroz AC, Jones TC. Leishmania donovani: an opportunistic microbe associated with progressive disease in three immunocompromised patients. Lancet. 1986;1(8482):647-9.

7. Gradoni L, Scalone A, Gramiccia M. HIV-Leishmania co-infections in Italy: serological data as an indication of the sequence of acquisition of the two infections. Trans Roy Soc Trop Med Hyg. 1993;87(1):94-6.

8. Instituto Brasileiro de Geografia e Estatística. Mapas Temáticos. IBGE [Internet]. Available from: http://www.ibge.gov.br/mapas_ibge/tem.php.

9. Galati EAB, Nunes VLB, Rego FA Jr, Oshito ET, Chang MR. Estudo de flebotomíneos (Diptera: Psychodidae) em foco de leishmaniose visceral no Estado de Mato Grosso do Sul, Brasil. Rev Saúde Pública. 1997;31(4):378-90.

10. dos Santos SO, Arias J, Ribeiro AA, de Paiva Hoffman M, de Freitas RA, Malacco MA. Incrimination of Lutzomyia cruzi as a vector of American visceral leishmaniasis. Med Vet Entomol. 1998;12(3):315-7.

11. Morrison AC, Ferro C, Tesh RB. Host preferences of the sand fly Lutzomyia longipalpis at an endemic focus of American visceral leishmaniasis in Colombia. Am J Trop Med Hyg. 1993;49(1):68-75.

12. Camargo-Neves VLF. A leishmaniose visceral americana no estado de São Paulo: situação atual. BEPA Bol Epidem Paul. 2007;4(48).

13. Feliciangeli MD. Ecology of sadflies (Diptera: Psychodidae) in a restricted focus of cutaneous leismaniasis in northen Venezuela. III. Seasonal fluctuation. Mem Inst Osvaldo Cruz. 1987;82(2):167-76.

14. Brasil. Ministério da Saúde. Secretaria de Estado da Saúde. Manual de vigilância e controle da leishmaniose visceral americana no Estado de São Paulo. São Paulo: Secretaria de Estado da Saúde; 2006.

15. Forattini OP, Rabello EX, Pattoli DGB. Sobre o encontro de Lutzomyia longipalpis (Lutz \& Neiva, 1912) no Estado de São Paulo, Brasil. Rev. Saúde Pública. 1970;4(1):99-100.

16. Camargo-Neves VLF, Katz G, Rodas LAC, Poletto DW, Lage LC, Spínola RMF, Cruz OG. Utilização de ferramentas de análise espacial na vigilância epidemiológica de leishmaniose visceral americana - Araçatuba, São Paulo, Brasil, 1998-1999. Cad Saúde Pública. 2001;17(5):1263-7. 
17. Costa AIP, Casanova C, Rodas LAC, Galati EAB. Atualização da distribuição geográfica e primeiro encontro de Lutzomyia longipalpis em área urbana no Estado de São Paulo, Brasil. Rev Saúde Pública. 1997;31(6):632-3.

18. Tolezano JE, Luvizotto MCR, Uliana SRB, Araujo MFL, Taniguchi HH, Barbosa JAR, Barbosa JER, Pinto PLS, Winter LMF, Shaw JJ. Leishmaniose visceral americana (LVA) em Araçatuba, região oeste do Estado de São Paulo. Investigações laboratoriais e diagnóstico de uma doença emergente em terras paulistas. In: 35 Congresso da Sociedade Brasileira de Medicina Tropical, 1999. Rev Soc Bras Med Trop. 1999;32:218.

19. Camargo-Neves VLF, Katz G. Leishmaniose visceral americana no Estado de São Paulo. Rev Soc Bras Med Trop. 1999;32(Suppl 2):63-4.

20. Brener Z. Calazar canino em Minas Gerais. [Master's thesis]. Belo Horizonte: Universidade Federal de Minas Gerais, Faculdade de Medicina; 1957. 90 p.

21. Instituto Brasileiro de Geografia e Estatística. Cidades @. IBGE [Internet]. 2007. Available from: http://www.ibge.gov.br/cidadesat/.

22. Alves MCGP, Matos MR, Reichmann ML, Dominguez MH. Dimensionamento da população de cães e gatos do interior do Estado de São Paulo. Rev Saúde Pública. 2005;39(6):891-7.

23. Lindoso JAL, Lima VP, Goto H, Vergara MPP, Celeste BJ. Correlação clínica da resposta sorológica para Leishmania $s p$ em pacientes com aids atendidos no Instituto de Infectologia Emílio Ribas. In: Resumos do $23^{\circ}$ Reunião de Pesquisa Aplicada em Doença de Chagas e Leishmaniose, Uberaba; 2007. Uberaba [publisher unknown]; 2007.

24. Faculdades de Dracena. Histórico da Instituição. [Internet]. Dracena: Fundação Dracenense de Educação e Cultura. Available from: http://fundec.edu.br/unifadra/Historico_da_\%20Instituicao.doc.

25. Evans TG, Vasconcelos IAB, Lima JW, Teixeira JM, Mcaullife IT, Lopes UG, Pearson RD, Vasconcelos AW. Canine visceral leishmaniasis in northeast Brazil: assessment of serodiagnostic methods. Am J Trop Med Hyg. 1990;42(2):118-23.

26. Camargo ME, Rebonato C. Cross-reactivity in fluorescense tests for Trypanosoma and Leishmania antibodies. Am J Trop Med Hyg. 1969;18(4):500-5. 
27. Costa CA, Genaro O, Lana M, Magalhães PA, Dias M, Michalick MSM, Melo MN, Costa RT, Rocha NMM, Mayrink W. Leishmaniose visceral canina: avaliação da metodologia sorológica utilizada em inquéritos epidemiológicos. Rev Soc Bras Med Trop. 1991;24(1):21-5.

28. Steel RGO, Torrie JR. Principles and procedures of statistics. New York: McGraw-Hil Book Company; 1960. 481 p.

29. Barão SC, Camargo-Neves VLF, Resende MR, Silva LJ. Human asymptomatic infection in visceral leishmaniasis: a seroprevalence study in an urban area of low endemicity. Preliminary results. Am J Trop Med Hyg. 2007;77:1051-3.

30. Carvalho MR. Eco-epidemiologia da leishmaniose visceral americana na zona da mata norte de Pernambuco. [Master's thesis]. Recife: [publisher unknown]; 2005. $120 \mathrm{p}$.

31. Grupo de Estudos em Leishmaniose. Parecer técnico sobre a utilização de papel de filtro como meio de coleta de amostras de sangue para realização de exames de imunofluorescência indireta. São Paulo: [publisher unknown]; 2007.

32. Braga MDM, Coelho ICB, Pompeu ML, Evans TG, Macaullife IT, Teixeira MJ, Lima JWO. Controle do calazar canino: comparação dos resultados de um programa de eliminação rápida de cães sororreagentes por ensaio imunoenzimático com outro de eliminação tardia de cães sororreagentes por teste de imunofluorescência indireta de eluato de papel de filtro. Rev Soc Bras Med Trop. 1998;31(5):419-24.

33. Araújo MFL. Avaliação do antígeno recombinante $\mathrm{K} 39$, em teste imunocromatográfico, no diagnóstico da leishmaniose visceral canina endêmica na região noroeste do Estado de São Paulo, Brasil. [Master's thesis]. São Paulo: Programa de Pós-graduação em Ciências da C. C. D. Secretaria Estadual Saúde São Paulo; 2007. 